\title{
The Provincial Government's Authority Regarding the Post-Mining Activities
}

\author{
Alfi Soka Hananti ${ }^{1 *}$, F.C. Susila Adiyanta ${ }^{2}$, Muhamad Azhar ${ }^{3}$ \\ \{alfinyook@gmail.com ${ }^{* 1}$, susila.adiyanta@live.undip.ac.id ${ }^{2}$, azhar@live.undip.ac.id ${ }^{3}$ \}
}

Fakultas Hukum, Universitas Diponegoro, Jl. Prof. H. Soedarto, S.H., Semarang, Indonesia $50275^{1}$

\begin{abstract}
As a form of government action in the effort to exploit mineral resources in Indonesia, supervision, especially in the mineral and coal mining sector is carried out in order to supervise and control them so that the implementation of state control over these resources is truly carried out for the greatest prosperity of all people. This study aims to firstly, find out how the authority of the Central Java Provincial Government in supervising mining activities. Secondly, to know the juridical consequences of implementing supervision of mining activities in the Central Java region based on Law Number 23 of 2014 concerning the Regional Government. The research method used by researchers is the empirical juridical method. The study was conducted by reviewing the implementation or implementation of positive legal provisions regarding supervision in mining business activities based on factual events that occurred in the community in accordance with the data and facts found. The study discussed the supervision authority of the provincial government in supervising post mining activities and how they were implemented in the field before and after the ratification of Law Number 23 of 2014 concerning Regional Government. The results of the study indicate that supervision has not been running as it should.
\end{abstract}

Keywords: Provincial Authorities, Oversight, Mining Activities, Law Number 23 Of 2014 concerning Regional Government

\section{Introduction}

Indonesia has always been famous for its rich natural resources in the fields of agriculture, fisheries and even mining [1]. Each region of Indonesia has its own natural potential, especially in the fields of oil and gas (oil and gas), as well as minerals and coal (minerals). In addition, natural resources are also abundant in the mining sector, such as: gold, copper, silver, petroleum, and geothermal. Potential mineral mining resources are spread in 437 locations in western and eastern Indonesia, including copper and gold in Papua, gold in Nusa Tenggara, nickel in Sulawesi, bauxite and coal in Kalimantan and other minerals scattered in various places [1].

Paragraph four of the opening of the 1945 Constitution of the Republic of Indonesia (1945 Constitution) emphasizes the country's goal to protect the entire nation of Indonesia and all of Indonesia's blood spills, as well as to advance public welfare, improve the life of the nation, and participate in implementing world order based on independence, lasting peace and social justice.[2] Article 33 Paragraph (3) of the 1945 Constitution of the Republic of Indonesia states that "Earth, water and natural resources contained therein are controlled by the state and used for the greatest prosperity of the people". This provision is an affirmation of the phrase promoting public welfare in the opening of the 1945 Constitution of the Republic of 
Indonesia, thus the state obtains constitutive legitimacy to control and carry out governance of the earth, water, and natural resources to be used for the greatest prosperity of the people.

The right to control the state is the authority of the state to regulate, manage and supervise the management or exploitation of minerals, and contains the obligation to use it as much as possible for the prosperity of the people. State control is held by the government.[3] Thus, the role of the government in the mining sector in relation to the ownership rights has becomes very important to manage the wealth of natural resources so that it can be enjoyed by many people with the aim of creating a just and prosperous society.[4] The state is obliged to be present in order to manage and oversee the public service branches, so that the results can be used for the amount of prosperity of the people.[5] The word "controlled by the State" indicates the existence of a character state that has sovereignty, so that it can act in and out. So in this case the use of the word "controlled by the state", means referring to the control and implementation by the central government. Article 33 of the 1945 Constitution of the Republic of Indonesia refers to "authority rights" over mineral materials in the hands of the state, not the government.[6]. On the other hand, mineral rights to the minerals are in the hands of the Indonesian people (all Indonesian people). Likewise, mining rights are in the hands of the government and economic rights are in the hands of business actors.[7]

The 1945 Constitution of the Republic of Indonesia gives a mandate to the state through executive institutions to conduct policies (regulations) and management measures (bestuursdaad), regulation (regelendaad), management (beheersdaad), and supervision (toezichthoudensdaad) for the purpose of the maximum prosperity of the people.[8] The oversight function by the state (toezichthoudensdaad) is carried out by the state, c.q. the government, in order to supervise and control so that the implementation of control by the state of the said resources is truly carried out for the greatest prosperity of all people. [9] The word "controlled by the government" can also mean the local government [10]

One form of supervisory authority carried out by the government is by issuing permits for the management of Energy and Mineral Resources (ESDM). The authority is given to local governments because not all regions in Indonesia have the same EMR potential. This is intended to be more effective control and coordination.

Supervision of the use of ESDM is very important and carried out by the government so that the practice does not deviate from Article 33 paragraph (3) of the 1945 Constitution of the Republic of Indonesia, which is to be used for the greatest prosperity of the people. Supervision also aims to ensure that exploration and exploitation activities by companies are carried out properly in accordance with applicable rules and are expected to not cause damage in the future. Supervision is carried out in the form of granting permits for the use of mining resources for legal subjects (legal entities, cooperatives and individuals).

Supervision in principle is done as a preventive measure whether the activities carried out in accordance with existing provisions.[11] Supervision of mining business activities is basically aimed at making IUP holders more focused in conducting business activities. In theory, George R. Terry argues that supervision is intended to determine what has been achieved, evaluated, and implemented in corrective actions if necessary, in order to ensure the intended results.[12] Relevant to this opinion, supervision is absolutely necessary in the management of mining businesses in accordance with the principle of the goal of supervision, so that it does not deviate from the permit.

ESDM governance is mandated to local governments based on the principle of autonomy and co-administration (mede bewind). The application of these principles means that the central government gives special authority to regional governments to manage and manage their respective regions. In Law Number 23 Of 2014 concerning Regional Government (UU 
Pemda), the authority to grant mining permits is shared between the central government and the provincial government.

The wide open authority in the regions makes the opportunity for abuse of governmental authority even greater. Opportunities for corruption, collusion and nepotism (KKN) by government officials and mining businesses generally begin at the licensing stage. There are opportunities to manipulate land area in exploitation activities such as manipulation of land ownership documents by individual company employees and local government officials [13] This clearly violates the mandate of the Article 33 paragraph (3) of the 1945 NRI Constitution which states that the utilization of natural resources must be based on the interests of the people's prosperity.

This is where the role of supervision is needed. The aim is to increase public legal awareness of the importance of orderly administration, especially in the mineral and coal sector.

Based on the description above, the main problem identification and formulation are as follows:

1. What is the authority of the Central Java Provincial Government in supervising mining activities after the enactment of Law Number 23 of 2014 concerning Regional Government?

2. What are the juridical consequences of implementing supervision of mining activities in the Central Java region based on Law Number 23 of 2014 concerning Regional Government?

\section{Method}

This research uses empirical juridical methods. Data processing and analysis in this research was done analytically descriptive. Regulatory impact assessment (RIA) method is used to analyze legal issues. This method is a process of systematic analysis and communication of policies, both new policies and existing policies [14]. Scientific activities include field research and comparative studies of legal materials.

\section{Results and Discussion}

\subsection{Central Java Provincial Government Authority}

\subsubsection{Supervision in Mining Permits in Central Java Province}

In the life of the nation and state, the system of governance is a decisive factor [15]. Supervision is part of the government's actions to prevent violations of the applicable provisions [16]. The Central Java Provincial Government in exercising the authority to supervise mining activities is based on several laws and regulations including the Minerba Law, the PPLH Law, the 2014 Regional Government Law, and the related implementing regulations below. This is in line with the concept of the rule of law, namely the principle of legality. All government actions must come from positive law. Every state administration official in acting (carrying out his duties) must be based on the legal authority given the legislation. Thus, every act of state administration officials must have a legal basis. Therefore, 
each state administration official must carry out a legal authority prior to carrying out his duties based on statutory regulations [17].

The mining permit implementation according to the Minerba Law is carried out in a decentralized manner based on the principle of broadest autonomy. This system refers to the provisions in Law Number 32 of 2004 concerning Regional Government (now replaced by the 2014 Local Government Law). This law confirms that the management of the mineral and coal sub-affairs is divided into three parties namely: the central government; provincial regional government; and district/city government.

The implementation of supervision according to this Law uses the principles of externality, accountability, and efficiency by taking into account the harmony of relations between government structures [18]. The field of mining affairs is included in matters of an optional nature, namely matters that actually exist and have the potential to improve the welfare of the community in accordance with the conditions, uniqueness, and superior potential of the region concerned [19], so that the determination of the distribution of IUP awarding functions is divided based on the distance that can be reached by each government. The Province has the authority to grant IUP, Production Operation IUP for mining business activities that exist in cross-regency/city areas within a range of four to 12 miles; Whereas districts/cities in granting IUP, Production Operation IUP and IPR for mining business activities that are in the district/city area up to four miles [20].

The authority to supervise mining activities that have a direct impact on the environment belongs only to the provincial government. Concentration is applied to facilitate investigation and verification in the case of violations by business actors which result in environmental pollution/damage. Whereas, the regional government only focuses on granting IUP, IUP Production Operation and IPR in its area, especially IPR which is a milestone in the local economy. The authority to grant IPR by the regency/city government is based on the ownership of the WPR area which does not exceed 25 hectares [21] and the number of mining points that are not small. Therefore, this authority is given to local governments because they are considered to be more understanding about the conditions, potential and threats of their respective regions.

The birth of the 2014 local government law gave several changes to the affairs of the regional government in managing mineral and coal mining [22]. There are fundamental differences regarding the division of concurrent government affairs in the Regional Government Law. The deconcentration system appears to be more dominant in the distribution of concurrent government affairs. It changes to this system of authority include, among others, the maritime and mining sector. At present the division of authority no longer exists on three parties, but there are only two namely the central government and the provincial government.

This change in management paradigm is basically done so that all arrangements regarding the use of mineral resources become more effective and efficient, because the entire licensing process is currently centered on the province. Seen from the details of the arrangement regarding the relationship between the center and the regions shows the government's desire to tidy up the existing order and authority in the provincial and district/city regions.[22] Supervision is more controlled because it is carried out directly by provincial officials.

At present the district/city government no longer has authority in carrying out affairs in the field of mineral and coal. The Regency/City authority that was lost included making regulations related to ESDM, granting permits (except geothermal), guidance and supervision[23]. The authority to grant IUP, Production Operation IUP in the regency/city area up to a distance of four miles is now drawn to the province. No exception to the granting of IPR which is now the authority of the provincial government. 
This formal change in the paradigm of division of affairs has certainly led to clashes between legal forms. This is because the Minerba Act as a sectoral law (lex specialis) should refer to the general law (lex generali). Conflicts of norms occur because of district/city regional authority, such as the authority to determine the WPR and issue IUP which in the Minerba Act becomes the authority of the regent/the mayor switches to provincial authority. The transfer of authority is not accompanied by revocation of the authority of supervision and violation of sanctions to holders of IPR, IUP or IUPK. Legally the authority is still attached to the regent/mayor based on the valid Minerba Act and is still valid as a positive law. Such behavior can be seen for example for the supervisory authority in Article 140 Paragraph (3) as well as the imposition of sanctions in the form of revocation of IUP and IUPK in Article 119 of the Mining Law which according to Article 409 of the Regional Government Law revokes several laws, excluding the Minerba Law.

This problem can be solved using the principle of lex posterior derogat legi priori ie the latest law (lex posterior) overrides the old law (lex prior).[23] The enactment of the Minerba Act is still valid as long as the Local Government Law does not regulate certain matters, so both of these regulations are still legally valid.

At present, the authority to supervise mining activities is carried out by the central government (ministers and governors). Although the autonomous region no longer has the authority to supervise, the role of the district/city regional government is still needed in providing recommendations on the determination of WIUP. Thus, the district/city regional government does not necessarily lose its power in its own territory. However, all supervisory decisions remain at the center as long as determined by legislation.

\subsubsection{Stages and Procedures}

a. Stages and Procedure for IUP Application

Applications for mining business licenses are divided into three types, namely request for WIUP, application for Exploration IUP, and application for Production Operation IUP [24]. To obtain an IUP as intended, prospective applicants must submit an application to the Head of the Regional Investment Board (BPMD) now DPMPTSP) by fulfilling four requirements namely administrative requirements, technical requirements, financial requirements, and environmental requirements [25]. These requirements must be met by prospective applicants who function as the first filter in the framework of direct supervision. This requirement refers to the Decree of the Minister of Energy and Mineral Resources of the Republic of Indonesia Number 1796 K / 30 / MEM / 2018 concerning Guidelines for Implementing, Evaluating, and Issuance of Licensing in the Mineral and Coal Mining Sector.[26]

Another thing that needs to be considered before submitting the application prerequisite is the Application Requirements Evaluation Sheet. After all the requirements have been met, the applicant can fill out an evaluation sheet in accordance with the business license requested.

Upon the request, the person receiving the request verifies the completeness document. An application that has fulfilled the document requirements will be given a receipt. Application documents received are submitted to the Technical Unit for evaluation [27].

After the documents are evaluated and met the requirements,, the technical unit prepares the draft decree. Requests that have fulfilled the requirements will be given a receipt. Application documents received are submitted to the technical unit. 
Then the IUP Decree is signed by the Minister or the Governor, in accordance with his authority or by the Head of the Provincial One-Stop Investment/Integrated Service Coordinating Board who is granted authority[27]. Decrees that have been signed are numbered and dated in accordance with the respective official script, for the applicant and copies for archives and copies and a Decree is conveyed to the applicant [27].

\section{b. Supervision Steps and Procedures}

Supervision is carried out directly and indirectly. Direct supervision is carried out by visiting the mining site. Activities in the form of checking directly to the location/field in accordance with the coordinates listed. This check is carried out by the mine inspector who has been appointed by the authorized official. Whereas indirect supervision is carried out without visiting the place of implementation of the supervised activity or work, or in other words carried out remotely by studying and analyzing all documents concerning the object being supervised. This supervision takes place at the permit application stage and also after the permit issuance. In the application process, supervision is carried out by way of providing a community survey. Meanwhile, postlicensing supervision is carried out through monitoring of the results of evaluations of reports on the implementation of mining activities.

\subsection{Juridical Consequences of Supervision of Mining Activities in the Central Java Region}

\subsubsection{Juridical Consequences of Supervision of Mining Activities in Central Java}

Juridical consequences of the supervision of the mining business that is granting permits and sanctions. Permission will be issued after going through the evaluation and checking process. The provincial Energy and Mineral Resources Office issued an IUP recommendation as one of the prerequisites for the mining business licensing process. The following is a table for publishing IUP technical recommendations in the Central Java region from 2016 to 2019.

Table 1. Issuance of IUP Technical Recommendations in Central Java (2016-2019)

\begin{tabular}{|c|c|c|c|c|}
\hline $\begin{array}{l}\text { Issuance of Technical IUP } \\
\text { Recommendations/Year }\end{array}$ & 2016 & 2017 & 2018 & 2019 \\
\hline WIUP & 402 & 306 & 179 & 134 \\
\hline Exploration IUP & 350 & 230 & 148 & \\
\hline Production Operation IUP & 192 & 177 & 117 & 70 \\
\hline OP Sales IUP & 32 & 58 & 52 & 36 \\
\hline $\begin{array}{l}\text { IUP OP } \\
\text { Processing/Purification }\end{array}$ & 17 & 24 & 30 & 6 \\
\hline IUJP Mining & 4 & 16 & 5 & 8 \\
\hline
\end{tabular}

The initial purpose of withdrawing supervisory authority to the provincial government is one of which is to centralize administration, so that the licensing bureaucracy becomes more efficient, effective and targeted. As explained, supervision is currently carried out by the provincial EMR office which was previously carried out by the district/city EMR office. 
However, it seems that the goal was not successful if you look at the data presented in the table.

Changing the bureaucratic system of mining business licensing are precisely the consequences of falling demand and the issuance of technical IUP recommendations each year. Data such as those listed above were taken after the enactment of the Regional Government Law in 2014. It can be seen from the table that the issuance of IUP recommendations conducted by the Central Java Provincial Energy and Mineral Resources Office tends to decrease rather than increase. An example can taken from the recommendations of WIUP, IUP Exploration, and Production Operation IUP where the average annual decline reaches half of the previous year's achievements.

Based on interviews with sand and stone mining businesses, some of them complained about the same thing. Concentration of licensing at the provincial level is even more troublesome because it forces businesses to take care of permits directly to the provincial capital. Businesses must prepare more costs and time to take care of licensing. This problem was then also supported by the unavailability of the Online Single Submission (OSS) system in mining licenses.

Supervision currently carried out by the province causes the reach of mining entrepreneurs to be even further. To get a permit, the entrepreneur must take care of the province which is further away. As a result, entrepreneurs become lazy to take care of mining business licensing. This led to a decline in mining business permit applications. The decrease in this request is then directly proportional to the level of legal awareness of mining entrepreneurs. The entrepreneurs finally choose to run their business without obtaining a permit. This illegal practice is referred to as mining without permission (PETI). In addition, the factor of mining mining activities which increased along with the need for infrastructure development in Central Java, also did not rule out the possibility of an impact on the rise of PETI [31].

These forms of PETI is vary. There are practices of PETI carried out by individuals and business entities with no bagging IUP at all [32]; there is a violation committed by a licensed businessman but has expired but does not immediately renew; and there is also the practice of PETI in the form of mining production operations (processing and refining) even though the entrepreneur only has an Exploration IUP [33]. These illegal practices not only harm the country's goal of advancing public welfare, but are also harmful to environmental sustainability and safety.

Table 2. Ordering Illegal Mining Areas in Central Java (2013-2017)

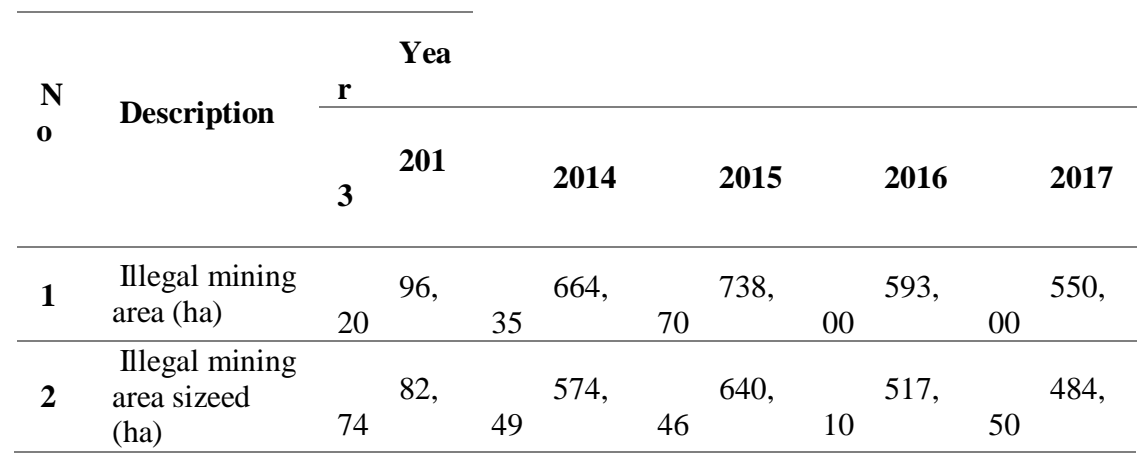




\subsubsection{Solutions to the Obstacles to the Implementation of Supervision of Mining Activities in the Central Java Region}

The solution that can be done by the government is to maximize the resources available at the provincial EMR office to facilitate mining entrepreneurs who lack knowledge of regulations and administration. This is done by empowering regional officials well, such as by appointing district/city-level service officers to supervise mining in the regions. And by renewing the sectoral mining law.

\section{Conclusion}

The authority of the Central Java provincial government oversight of mining business activities covers the entire series of business activities starting from the pre-application of permits to post-mining activities in Central Java in carrying out the duties and authority of supervision. The basis for the placement of this supervisory authority refers to Law Number 23 of 2014 concerning Regional Government. Supervision is carried out directly and indirectly by technical officials. Direct supervision is carried out by visiting mining business locations based on existing coordinates. Indirect supervision is carried out through the provision of IUP recommendations and periodic evaluation and inspection of mine activity reports.

The consequence of supervision in mining business activities is the provision of permits and sanctions. Research shows that there is instability in achieving supervision. Several obstacles that impede the implementation of supervision stemmed from overlapping rules. In this case, it can be concluded that the supervision of the granting of permits and sanctions in relation to the current deconcentrating system has not been running well.

The suggestions that can be conveyed in writing this law include: 1) directing the preparation of good administration by counseling mining entrepreneurs; 2) empowering regional officials well, such as by appointing district/city-level service officers to supervise mining in the regions; and 3) reforming the mining sector regulations by the government to avoid overlapping regulations. The current Minerba Act still refers to the existing provisions in the old Local Government Law. Even though the implementation of the Minerba Law is still valid and recognized positively, the renewal is needed to create a harmony and legal certainty. 


\section{References}

[1] M. Azhar, Buku Ajar Hukum Pertambangan. Semarang: Lembaga Pengembangan dan Penjaminan Mutu Pendidikan Universitas Diponegoro, 2019.

[2] Paragraph four (IV) of the opening of the 1945 Constitution of the Republic of Indonesia (1945 Constitution). .

[3] S. HS., Hukum Pertambangan Indonesia. Jakarta: Rajawali Pers, 2012.

[4] M. Azhar and S. Suhartoyo, "Aspek Hukum Kebijakan Geothermal Di Indonesia," Law Reform, vol. 11, no. 1, pp. 123-138, 2015.

[5] N. Trihastuti, Tanah Tambang dan Masyarakat Hukum Adat. Bandar Lampung: Idepth Publishing, 2014.

[6] T. Hayati, "Hak penguasaan negara terhadap sumber daya alam dan implikasinya terhadap bentuk pengusahaan pertambangan," J. Huk. Pembang., vol. 49, no. 3, pp. 768-787, 2019.

[7] T. Hayati, Era Baru Hukum Pertambangan: Di Bawah Rezim UU No. 4 Tahun 2009. Jakarta: Yayasan Pustaka Obor Indonesia, 2015.

[8] H. Purnomo, Kompilasi Putusan Pengujian Undang Undang oleh Mahkamah Konstitusi. Jakarta: Komisi Yudisial RI, 2015.

[9] Decision of the Constitutional Court Number 001-021-022 / PUU-I / 2003 concerning Case Testing of Law Number 20 of 2002 concerning Electricity to the 1945 Constitution of the Republic of Indonesia, December 21, 2004. .

[10] T. Hayati, Perizinan pertambangan di era reformasi pemerintahan daerah: studi tentang perizinan pertambangan timah di Pulau Bangka. Jakarta: Badan Penerbit Fakultas Hukum Universitas Indonesia, 2012.

[11] F. Puluhawa, "Substansi Hukum Tentang Pengawasan Izin Pada Usaha Pertambangan," J. Pelangi Ilmu, vol. 3, no. 4, 2010.

[12] J. Hamidi and M. Lutfi, "Eksistensi Komisi Ombudsman Nasional dalam Mewujudkan Good Governance," Majalah Hukum Varia Peradilan, 2009.

[13] Badan Pembinaan Hukum Nasional, Analisis dan Evaluasi Pengelolaan Sumber Daya Alam. Jakarta: Kementerian Hukum dan Hak Asasi Manusia Republik Indonesia, 2015.

[14] Kementerian PPN/Bappenas, Pengembangan dan Implementasi Metode Regulatory Impact Analysis (RIA) untuk Menilai Kebijakan (Peraturan dan Non Peraturan) di Kementerian PPN/BAPPENAS. Jakarta: Kementerian PPN/Bappenas, 2011.

[15] M. Azhar, "Relevansi asas-asas umum pemerintahan yang baik dalam Sistem penyelenggaraan administrasi Negara," Notarius, vol. 8, no. 2, pp. 274-286, 2015.

[16] K. C. S. Wibawa, "Mengembangkan Partisipasi Masyarakat Dalam Perlindungan dan Pengelolaan Lingkungan Hidup Untuk Pembangunan Berkelanjutan," Adm. Law Gov. J., vol. 2, no. 1, pp. 79-92, 2019.

[17] S. Nugraha, Hukum Administrasi Negara dan Good Governance. Pidato Pengukuhan Guru Besar Tetap Fakultas Hukum Universitas Indonesia. Depok: Universitas Indonesia, 2006.

[18] Article 11 paragraph (1) of Law Number 32 Year 2004 concerning Regional Government. .

[19] Article 13 paragraph (2) of Law Number 32 Year 2004 concerning Regional Government. .

[20] Article 7 and 8 of Law Number 4 of 2009 concerning Mineral and Coal Mining. .

[21] Article 22 letter d of Law Number 4 of 2009 concerning Mineral and Coal Mining. .

[22] N. D. Putri and D. A. Wicaksono, "Implikasi legislasi pengambilalihan kewenangan di 
bidang pertambangan mineral dan batubara oleh pemerintah pusat," J. Legis. Indones., vol. 13, no. 1, pp. 19-32, 2018.

[23] R. Perdana, Implikasi Perubahan Pembagian Urusan Pemerintahan Berdasarkan Undang-Undang Nomor 23 Tahun 2014 tentang Pemerintahan Daerah. Jakarta: Biro Hukum Kementerian PPN/Bappenas, 2016.

[24] Dinas Energi dan Sumber Daya Mineral Jawa Tengah, "Tata Cara Izin Usaha Pertambangan." [Online]. Available: https://esdm.jatengprov.go.id/download/perizinan/TATA_CARA_MENGAJUKAN_I ZIN_USAHA_PERTAMBANGAN.pdf. [Accessed: 18-Dec-2019].

[25] Article 40 Governor Regulation of Central Java Number 18 Year 2016 concerning Service Delivery in the Field of Energy and Mineral Resources in the Province of Central Java. .

[26] Decree of the Minister of Energy and Mineral Resources of the Republic of Indonesia Number 1796 K / 30 / MEM / 2018 concerning Guidelines for Implementing, Evaluating, and Issuance of Licensing in the Mineral and Coal Mining Sector. .

[27] Regulation of the Minister of Energy and Mineral Resources No. 34 of 2017 concerning Licenses in the Field of Mineral and Coal Mining. .

[28] Dinas Energi dan Sumber Daya Mineral Provinsi Jawa Tengah, "Laporan Kinerja Instansi Pemerintah ESDM Jateng Tahun 2016,” 2017. [Online]. Available: https://ppid.esdm.jatengprov.go.id/dokumen/kegiatan-kinerja/LKjIP-2016.pdf, $\quad$ or https://ppid.esdm.jatengprov.go.id/LKj-IP.html. [Accessed: 10-Mar-2020].

[29] Dinas Energi dan Sumber Daya Mineral Provinsi Jawa Tengah, "Laporan Kinerja Instansi Pemerintah ESDM Jateng Tahun 2017," 2018. [Online]. Available: https://ppid.esdm.jatengprov.go.id/dokumen/kegiatan-kinerja/LAKIP-2017.pdf. [Accessed: 10-Mar-2020].

[30] Dinas Energi dan Sumber Daya Mineral Provinsi Jawa Tengah, "Laporan Kinerja Instansi Pemerintah ESDM Jateng Tahun 2018,” 2019. [Online]. Available: https://ppid.esdm.jatengprov.go.id/dokumen/kegiatan-kinerja/LKjIP-2018.pdf. [Accessed: 10-Mar-2020].

[31] Dinas Energi dan Sumber Daya Mineral Provinsi Jawa Tengah, "Rancangan Strategis Dinas ESDM Provinsi Jawa Tengah Tahun 2018-2023." [Online]. Available: https://esdm.jatengprov.go.id/download/Renstra-Dinas-ESDM-Provinsi-Jawa-TengahTahun-2018-2023.pdf. [Accessed: 10-Mar-2020].

[32] Article 158 of Law Number 4 of 2009 concerning Mineral and Coal Mining. .

[33] Article 160 paragraph (2) of Law Number 4 of 2009 concerning Mineral and Coal Mining. . 